\title{
MUSINGS ON THE DYNAMICS OF CORPORATE GOVERNANCE ISSUES, DIRECTOR LIABILITY CONCERNS, CORPORATE CONTROL TRANSACTIONS, ETHICS, AND FEDERALISM ${ }^{\dagger}$
}

\section{E. NORMAN VEASEY ${ }^{\dagger}$}

\section{INTRODUCTION}

When I was a first-year student at this Law School nearly fifty years ago, one or more of the professors who reorganized our brains asked us in several policy contexts what Moses would do. We were asked to step back in the context of the Socratic discussion of a particular case or principle of law and visualize the answer to big policy questions.

Moses, of course, was a humble man and tended to understate his own importance. Having seen the burning bush and having received Divine guidance and powers, he strove to carry out God's mission. I do not have the talent or the Divine guidance and powers that Moses received. Thus, I cannot be the instrument to part the waters or to take us to the Promised Land by solving and mediating the conflicting philosophies and interpretations of our jurisprudence as analyzed by the brilliant scholars at this Symposium.

This Symposium is devoted to in-depth treatment of the law and economics issues inherent in control transactions. There are a dozen scholarly papers presented to this Symposium. These papers and the commentary that followed shine the kleig lights on many important aspects of this large and complex area. An after-dinner speech is not the right vehicle to try to rationalize all these issues. Even if I had the talent to do that-which I do not-it would not be ethical for me to do so. So I will take some refuge in my judicial position and say absolutely nothing of any depth or importance.

With that mission in mind, I will try to speak more broadly-but briefly-about the corporation law. In the course of these somewhat superficial ridge-running remarks, I will touch on the dynamics of corporate governance issues, director liability concerns, corporate control transactions, ethics, and federalism.

\footnotetext{
'Address at the University of Pennsylvania Law School Symposium on Control Transactions, February 8, 2003.

"Chief Justice of the Delaware Supreme Court.
} 


\section{CORPorate Governance}

In the 1990s, while the economy and the securities markets were on the ascendancy, there was a huge paradox developing. The transactions and corporate behavior that led to the demise of Enron, Worldcom, and others were festering like an undetected carcinoma. At the same time, in other venues, there was a strong movement toward best practices in corporate governance. That movement was internally generated in several corporations and was encouraged by judges, counselors, the American Bar Association (ABA), academics, institutional investors, and organizations.

Simultaneously and perhaps relatedly, there was in part a reform movement evolving in the realm of lawyer ethics. The American Law Institute was working on its Restatement of the Law Governing Lawyers ${ }^{1}$ and the ABA had initiated its Evaluation of the Model Rules of Professional Conduct, known as Ethics $2000 .^{2}$ As it turns out, the Sarbanes-Oxley Act of $2002^{3}$ involved a bit of a convergence of corporate governance and professional responsibility. More about that later.

First, I want to touch on the dynamics of corporate governance in the context of the standards of conduct of corporate directors. I use the term "standards of conduct" deliberately because I think we will agree that it is helpful to separate standards of conduct from standards of liability of directors. Courts expect directors to act independently, with due care and in good faith not only in making business decisions, but also in their oversight responsibilities. Liability may or may not follow a failure to live up to these aspirational standards.

Structural changes such as the movements toward a preponderance of independent directors, executive sessions of independent directors, and other best practices are good developments in enhancing the expectations of standards of conduct. Although state law generally governs internal affairs of corporations, Delaware law is enabling and does not spell out issues like the details of independence. And rightly so, but now some of these corporate governance reforms are being governed, as to some corporations and influenced as to others,

1 RESTATEMENT (THIRD) OF THE LAW GOVERNING LAWYERS (2000).

2 Comm'n on Evaluation of the Rules of Prof'l Conduct, Am. Bar Ass'N, REPORT OF THE COMMISSION ON EVAluation OF THE Rules OF Professional. CONDUCT (2000).

${ }^{3}$ Sarbanes-Oxley Act of 2002, Pub. L. No. 107-204, 116 Stat. 745 (codified in scattered sections of 11 U.S.C.A, 15 U.S.C.A, 18 U.S.C.A, 28 U.S.C.A, 29 U.S.C.A). 
by the Sarbanes-Oxley Act, the SEC Rules, and the proposed listing requirements of the New York Stock Exchange and NASDAQ. Yet, most aspects of corporate internal affairs and lawyer ethics continue to be governed by state law, and that mostly means judicially created and enforced fiduciary duty law.

The keystone of state-based corporation law is the business judgment rule. Investors expect loyal directors to take prudent, carefully considered, good faith business risks for the economic gain of the enterprise. Courts are ill-equipped to second-guess business decisions, so courts focus on loyalty, independence, good faith, and process.

Although the business judgment rule is not strictly applicable to the directors' oversight responsibilities, the fiduciary duties of good faith, loyalty, and due care are. From Chancellor Allen's Caremark ${ }^{4}$ decision in 1996 we see that the courts will measure the directors' standard of conduct and standard of liability by evolving yardsticks depending on modern developments. In that case we see an emphasis on the good faith standard.

There is some debate about whether good faith really is one of the fiduciary duties or whether it is subsumed in the duty of loyalty. Although the duty of good faith may be subsumed in the duty of loyalty, the opposite may not be true. Thus, I think it may be accurate to consider the duty of good faith as an additional duty beyond the duty of loyalty, at least for some purposes. Certainly, a director who sublimates the corporate interest to the director's own personal interest is probably acting disloyally and is probably not acting in good faith. But perhaps not all failures to act in good faith will necessarily implicate disloyal concepts of self-interest or self-dealing.

In my opinion, good faith requires an honesty of purpose and eschews a disingenuous mindset of seeming on the surface to act for the corporate good, but not caring for the well-being of the constituents of the fiduciary. Although the concept of good faith is not fully developed in the case law, an argument could be made that reckless, irresponsible, or irrational conduct but not necessarily self-dealing or larcenous conduct could implicate concepts of good faith. Moreover, in the new, post-Enron era of corporate responsibility requiring new standards mandated by Congress, rules of self regulatory organizations (SROs), or voluntary best practices, good faith may emerge as a central issue of the directors' standard of conduct. It may or may not emerge as a standard of liability, however.

${ }^{4}$ In re Caremark Int'l, Inc. Derivative Litig., 698 A.2d 959 (Del. 1996). 
Irrationality is the outer limit of the business judgment rule and may be the functional equivalent of the waste test or it may show that a decision is not made in good faith. If the board's decision or conduct is irrational or so beyond reason that no reasonable director would credit the decision or conduct, lack of good faith may, in some circumstances, be inferred.

It is important to corporate America that we have directorial candidates who are willing to serve, and that they be provided with adequate pay, indemnification, and insurance. Sarbanes-Oxley may have shrunk the universe of those candidates, but that is another issue for another day. Directors should not be seen as guarantors of good results or preventors of the malfeasance, misfeasance, or nonfeasance of others. They should be entitled to rely in good faith on corporate documents, committees, and experts to a significant degree in making their business judgments. And they should not be held personally liable for negligence. In this connection, the Delaware statutory law may come to aid the director.

Section 141(e) of the Delaware General Corporation Law provides that directors shall be "fully protected" in relying in good faith upon corporate records, reports of officers or committees of the board, or experts that the director "reasonably believes" to be opining within that person's expertise and who has "been selected with reasonable care by or on behalf of the corporation." But if the facts cast doubt upon that presumption of good faith reliance or selection with reasonable care, the director may have fallen short of an expected standard of conduct. Whether the director will resultantly be exposed to liability is another question that will depend on the standard of review applied to the circumstances. Indeed, Sarbanes-Oxley may play a role in certain cases.

Section 102(b) (7) of the General Corporation Law permits the stockholders to include in the certificate of incorporation a provision exonerating directors from personal liability in damages for mere due care violations, but not for "breach of the director's duty of loyalty to the corporation or its stockholders" or for "acts or omissions not in good faith or which involve intentional misconduct or a knowing violation of law." Moreover, the statute does not eliminate due care as a standard of conduct, thus leaving it not only as an aspirational goal, but also an expectation. A breach of the duty of care can be a basis

\footnotetext{
${ }^{5}$ DEL. CODE ANN. tit. 8, §141(e) (2001).

${ }^{6}$ Id. $\$ 102(\mathrm{~b})(7)$.
} 
for equitable relief, as we see, for example, in some contests for corporate control. As far as the Delaware case law is concerned, however, the jurisprudence on good faith is unresolved.

\section{Control Transactions}

The debate on control transactions that we are in the process of hearing in this outstanding Symposium is an extraordinary symphony with half the orchestra playing in A major and the other half playing simultaneously in B-flat minor. The result is some discord, of course. Yet, there are some lasting melodies, or at least some phrases one can take away and hum.

It falls to the Delaware courts to articulate and apply economically coherent resolutions on a case-by-case basis. Some trash the way that the Delaware courts have handled this assignment. Others praise their work. Two quotes from the exposition of the paper by Richard Kihlstrom and Michael Wachter demonstrate this bipolar academic review of the performance of the Delaware courts in control transactions:

Ronald Gilson argues that the Delaware standard of management discretion is formalistic and incoherent, lacking an animating principle that explains why it protects shareholders' interests. More recently, Bernard Black and Reinier Kraakman have proposed principles to explain Delaware corporation law based on what they call a "hidden value" model. However, they quickly conclude that the Delaware takeover cases are inconsistent with their reading of the empirical evidence and with each other. ${ }^{7}$

To this, Kihlstrom and Wachter add their own conclusion, stating in part: "[W] hen faced with the risk of fracturing corporate policy goals, the Delaware courts' solution, which protects the ability of directors to manage to their best information, is, at least arguably, the best rule."

Who am I to judge that debate? But perhaps one sentence in one of the papers hit the nail on the head by analogizing the current jurisprudential construct to a paraphrase of Winston Churchill's

' Richard E. Kihlstrom \& Michael L. Wachter, Corporate Policy and the Coherence of Delaware Takeover Law, 152 U. PA. L. REV. 523, 523-24 (2003).

${ }^{8} I d$. at 575 . 
observation about democracy. That is, the Delaware model may be inadequate-except when compared to all the alternatives. ${ }^{9}$

One does see in our courts a diverse parade of animals. There are, for example, unsolicited tender offers; friendly tender offers; mergers after a market canvass; stealth mergers; a variety of lockups and other merger contract provisions; proxy contests; poison pills; white knights; restructurings; independent committees; the business judgment rule; Time-Wamer; ${ }^{10}$ QVC; ${ }^{11}$ Unocal/Unitrin; ${ }^{12}$ Revlon; ${ }^{13}$ Blasius; ${ }^{14}$ Liquid Audio $;^{15}$ Omnicare ${ }^{16}$ and concepts of compelling justification, entire fairness, the vicinity of insolvency, etc. What one sees in the debates we are having at this excellent Symposium is another set of variable alternatives-should the Delaware courts, or perhaps its legislature, stand pat, clarify, tweak, or dismantle its principles on control transactions? What are the tensions: property or entity primacy; stockholder or director primacy; change, clarify, or keep the current balance?

I have read some portions of all the papers submitted at this Symposium and some of the authorities relied on in those papers. I have

9 Lynn A. Stout, The Shareholder as Ulysses: Some Empirical Evidence on Why Investors in Public Corporations Tolerate Board Governance, 152 U. PA. L. REV. 667, 689 (2003).

${ }^{10} \mathrm{See}$ Paramount Communications, Inc. v. Time, Inc., 571 A.2d 1140 (Del. 1989) (refusing to impose a fiduciary duty to maximize immediate share value where the corporation has not initiated a bidding process to sell itself or abandoned its long-term business strategy).

1 See Paramount Communications, Inc. v. QVC Network, Inc., 637 A.2d 23 (Del. 1994) (holding that the sale or change of control imposes special obligations on the directors to seek the transaction offering the best value reasonably available to the stockholders).

${ }^{12}$ Unocal Corp. v. Mesa Petroleum Co., 493 A.2d 946 (Del. 1985); Unitrin, Inc. v. Am. Gen. Corp., 651 A.2d 1361 (Del. 1995). Together, these two cases stand for the proposition that intermediate scrutiny requires a court to determine (1) whether a defensive measure is draconian, by being either preclusive or coercive, and, if it was not draconian, (2) whether it was within a range of reasonableness.

${ }^{13}$ See Revlon, Inc. v. MacAndrews \& Forbes Holdings, Inc., 506 A.2d 173 (Del. 1985) (adopting heightened duties to seek the best value reasonably available to the stockholders in certain circumstances).

${ }^{14}$ See Blasius Indus. v. Atlas Corp., 564 A.2d 651 (Del. Ch. 1988) (concluding that conduct that interferes with shareholder voting is not reviewed under the business judgment rule, but rather, under the compelling justification standard).

${ }_{15}$ See MM Companies, Inc. v. Liquid Audio, Inc., 813 A.2d 1118 (Del. 2003) (applying the Blasius compelling justification standard, rather than the Unocal standard, to a board's defensive actions where those actions interfere with shareholders' voting rights).

${ }^{16}$ See Omnicare, Inc. v. NCS Healthcare, Inc., 818 A.2d 914 (Del. 2003) (holding that a court must first determine that defensive measures are not preclusive or coercive before scrutiny will shift to the range of reasonableness). 
also listened to the dialogue that followed the presentation of the papers today. Time, and the limitations on my own talents, prevent me from analyzing the essence of each paper and the comments that followed. There is some merit to some of the points made by some of the critics of Delaware jurisprudence and there is some merit to some of the points made by some of the defenders of Delaware jurisprudence. It is not appropriate for me in my current position-which will not last forever-to comment substantively on the points made by the critics and defenders.

But I think I can try to explore the context and history of our jurisprudence in order to put these debates into some perspective. First, most cases end in the Court of Chancery and are never appealed. Second, each of these cases comes to our courts in the context of what is often a mosaic of complex facts involving quite different structures. For example, the review by the courts of the directors' response to a pure hostile tender offer with no alternative being supported by the directors depends not only on the precise terms of the offer and the defenses in place pre-offer, but also on pre-offer and post-offer facts and circumstances. These kinds of scenarios may be quite different from cases, for example, that begin with a proposed merger of equals or even a cash-out merger agreement, followed by an unsolicited topping offer by a third party.

In the first type of scenario, one may ask whether there is a kind of naked "just say no" doctrine that permits directors willy-nilly to stonewall and hide indefinitely behind the poison pill or other fortresses, whether pre-offer or post-offer. There is no Delaware Supreme Court case that stands for this stark proposition. The cases that have come before the Delaware Court of Chancery and the Delaware Supreme Court involving hostile tender offers turn on an infinite variety of factual circumstances and nuanced judicial treatment. So the jargon of "just say no" must be qualified by adding that, normally, there must be more said or done by the directors in carrying out their fiduciary duties than simply saying "nyet!" How much more is the big and unanswerable question. In the second type of scenario, it may make quite a difference-often an outcome determinative difference-what the target board did pre-merger, what the circumstances were under which the contractual provisions came into being, and what the board did post-merger agreement and post-topping bid.

In all these types of cases and the many variations on these themes, the Delaware courts have used not only their equitable powers, but also their enormous practical experience to analyze each 
situation, consider all the facts presented, and apply the jurisprudential doctrines that seem to fit the situations. Of course, one may criticize those jurisprudential doctrines, their application, and the underlying policy being implemented. Indeed, litigants are often free to argue for sweeping jurisprudential change in the context of a specific case, such as that which happened in 1983 in Weinberger ${ }^{17}$ and then a few years later in the four landmark cases in the watershed year of 1985: Van Gorkom, ${ }^{18}$ Unocal, ${ }^{19}$ Household, ${ }^{20}$ and Revlon. ${ }^{21}$ Courts are like "clams in the water." We must wait for a case to articulate our jurisprudence. Although, as judges, we give speeches and write articles raising academic issues and exhorting directors to adopt best practices, we do not reach out and make ex cathedra pronouncements on reformulating our jurisprudence or forecasting how certain fact situations should be decided.

Often the central theme of the debate in the mergers and acquisitions area is which body has primacy to decide whether or not to accept certain proposals-the stockholders or the directors. The advocates of the property model favoring stockholder choice contend that the stockholders must have that choice although they would want the directors to negotiate for the best deal. By contrast, those who favor the entity model rest their policy choice on the primacy of director decision making, often to the point of saying that directors should be permitted to "just say no." As former Chancellor Allen and Vice Chancellors Jacobs and Strine have observed: "[T]he major participants in the debate seem to be talking past each other."22 Some of what follows includes a paraphrase of some other aspects of their fine

${ }^{17}$ See Weinberger v. UOP, Inc., 457 A.2d 701, 712-13 (Del. 1983) (overturning the traditional Delaware block method of valuation and adopting tools of modern corporate finance).

${ }^{18}$ See Smith v. Van Gorkom, 488 A.2d 858, 893 (Del. 1985) (imposing, for the first time, liability under the duty of care).

${ }^{19}$ See Unocal Corp. v. Mesa Petroleum Co., 493 A.2d 946, 953 (Del. 1985) (adopting an intermediate standard of review of defensive measures that has remained the central rule governing takeovers under Delaware law).

${ }^{20}$ See Moran v. Household Int'l, Inc., 500 A.2d 1346, 1353-55 (Del. 1985) (reviewing, for the first time, and upholding the "flip over" rights plan as a legitimate defensive measure under the business judgment rule).

${ }^{21}$ See Revlon, Inc. v. MacAndrews \& Forbes Holdings, Inc., 506 A.2d 173, 182 (Del. 1985) (holding, inter alia, that, when the sale of the corporation becomes inevitable, the duty of the board of directors changes from preservation of the corporate entity to maximization of the corporation's value at sale for the stockholders' benefit).

${ }^{22}$ William T. Allen, Jack B. Jacobs \& Leo E. Strine, Jr., The Great Takeover Debate: A Meditation on Bridging the Conceptual Divide, 69 U. CHI. L. REv. 1067, 1072 (2002). 
University of Chicago Law Review article published last year on the "Great Takeover Debate.".".

The property school largely adheres to the efficient market theory permitting corporate control to be transferred relatively freely between buyers and sellers. ${ }^{24}$ Under this model, the directors' only mandate is to advance the interests of stockholders. There is no significant directorial power that would interfere with perceived clear-cut benefits such as an all-shares, all-cash tender offer, and the only further immediate benefit granted to stockholders is that the board has had the opportunity to seek out a better value or convince the stockholders that not tendering is a better choice.

Those who adhere to the entity model view the corporation as a societal institution with a purpose broader than simply serving the economic advancement of stockholders. ${ }^{25}$ Often these adherents will emphasize that what is critical is long-term wealth maximization. Directors thus have an obligation to exercise an informed, good faith, independent judgment based on their honest view that the corporation's best interests are served by a strategy with which the current stockholders may disagree. The entity model adherents often believe that there is economic value in allowing boards to make these decisions.

Delaware does not slavishly embrace either model, but gives the board of directors a central role in corporate decision making, reserving stockholder assent for many fundamental transactions, such as charter amendments and mergers. Significantly, there persists a legislative silence, which has prompted the debate in its current form.

I agree with the observation of the Allen trio that "the Delaware judiciary's reaction to this debate has left neither of these schools fully satisfied." ${ }^{26}$ Maybe that is good-like a settlement where there are no clear-cut winners or losers. Generally speaking, it is true that the purpose of the corporation is to maximize stockholders' wealth. That goal is consistent with the property model, but Delaware jurisprudence provides directors with substantial authority-depending on the circumstance-to deploy the poison pill and to block takeover offers even if they may appear to be in the best interests of current stockholders. Directors often have judicially sanctioned discretion to

\footnotetext{
${ }^{23}$ Id.

${ }^{24}$ Id at $1074-76$.

${ }^{25} I d$. at $1076-78$.

${ }^{26}$ Id. at 1079.
} 
act in good faith, in the best long-term interests of the corporation, as they see it. Under some facts, they may reject a takeover offer favorable to the present holders when an independent board, acting carefully and in good faith, has concluded that the corporation will generate greater economic returns in the long run under a different strategy. To this extent, Delaware law is consistent with the entity model. Sometimes Delaware law allows the directors to consider other interests, particularly those of creditors in certain dire economic circumstances. Nevertheless, the permissible consideration of those interests, when juxtaposed with the primacy of stockholder interests, is an area of the law that some say is evolving and others say is unclear.

Needless to say, Delaware courts do not allow boards unfettered discretion to block takeover bids. This Symposium is exploring the categories and parameters of various regimes of judicial review under which directors must demonstrate the independence, reasonableness, and good faith of their actions. Some doctrines and applications are clear. Others still remain theoretically in the realm of open issues.

Returning to the observations of Allen et al., I agree that the status quo has been criticized for lacking "doctrinal purity," but I also agree that the status quo has not-at least so far-stymied mergers and acquisitions activity in the United States. ${ }^{27}$ Most merger and acquisition activity has ground to a halt for other reasons, and the current deals are quite different even from last year's models.

Yet, it is true, as the Allen trio observes, that neither the property modelists nor the entity modelists are entirely content. The property school sees too much room for directors to fend off unwanted offers and wishes for a system that gives stockholders a clear right to decide for themselves in many situations. To that end, the Allen trio has noted that "the property modelists have proposed various legislative solutions, even calling for federal legislation that would mandate stockholder choice." ${ }^{28}$ I will mention federal legislation in a minute. But, as far as Delaware legislative activity is concerned, the general assembly is usually in a minimalist mode in this area, largely because the Delaware Bar (consisting of advocates for both stockholders and directors) is in that mode. Both are generally content to have the courts work out these complexities on a case-by-case basis, perhaps, in part, out of the fear of unintended consequences.

$\begin{array}{ll}{ }_{28}^{27} & I d . \text { at } 1081 . \\ & I d . \text { at } 1082 .\end{array}$ 
I will conclude this Part with observations of Allen, Jacobs, and Strine:

$[R]$ ather than being practical about the resolution of their differences, the two schools have opted for ideological purity, talking past each other and never really seeking out common ground.... [B]y adhering to its current perspective, neither school is likely to have its view adopted in full by judges forced to decide between them without clear legislative guidance.

Of course, the Allen trio has offered its own legislative solution. I will not comment on that or other legislative proposals except to note that there may be legislation in Delaware this year to provide for personal jurisdiction in the Delaware courts over officers as well as directors, who are already subject to that jurisdiction. Assuming no Delaware legislation in the mergers and acquisitions area is forthcoming in the near term, corporate planners must continue to navigate around some relative safe harbors and read the tea leaves in structuring or attacking the more aggressive deals that go into uncharted waters. That may not be easy, but it may not be all bad, either, particularly when compared to concerns about unintended consequences or overcorrecting that may lurk in some legislative solutions.

\section{FEDERALISM}

Now, let me turn to federal activity. Going back to Professor Bill Cary in the 1970s, there has been an ebb and flow of academic talk about a "silver-bullet" federal cure for perceived dissonance, uncertainty, and lack of intellectual purity in the way Delaware's three branches of government handle the internal affairs of corporations. ${ }^{30}$ It is true, as Chancellor Chandler and Vice Chancellor Strine suggest, that state courts may well be seeing fiduciary duty cases premised on what they have labeled as the "2002 Reforms." To some extent, Sarbanes-Oxley trumps state internal affairs law, or at least prescribes

Id.

${ }^{30}$ See William L. Cary, Federalism and Corporate Law: Reflections Upon Delaware, 83 YALE L.J. 663, 701-03 (1974) (proposing a Federal Corporate Uniformity Act that would create an umbrella of federal corporate responsibility guidelines). For a thorough discussion, see Robert B. Thompson \& Hillary A. Sale, Securities Fraud as Comporate Governance: Reflections upon Federalism, 56 VAND. L. REV. (forthcoming 2003).

31 See William B. Chandler III \& Leo E. Strine, Jr., The New Federalism of the American Comporate Governance System: Preliminary Reflections of Two Residents of One Small State, 152 U. PA. L. REV. 953, 953-54, 986-87 (2003) (noting that the Sarbanes-Oxley Act of 2002 and proposed stock exchange listing requirements, collectively termed the "2002 Reforms," will likely generate fiduciary duty cases in Delaware). 
specific requirements where state law is silent. As Chandler and Strine correctly observe, the 2002 Reforms have generated "creative friction with state [corporate] law" but this "should not be greeted by state policymakers with despair.,"32 Rather, it should inspire states to be a part of the solution.

In my view, many of the state law issues that we are currently seeing-as well as new ones-will continue to come before us. There will be additional considerations, of course, like the 2002 Reforms. Nevertheless, some of the same tensions between director and stockholder primacy that we are now seeing will continue.

Let me just say a word about the professional responsibility of corporate lawyers in the context of the federalism issue. First, corporate counselors are key in shaping the directors' adherence to fiduciary duties. Second, Sarbanes-Oxley and related developments put enormous pressure on the general counsel as well as outside counsel. That said, we need to put into perspective concerns about federalism issues in the area of lawyer ethics.

On January 29, 2003, the Securities and Exchange Commission (SEC) issued its final rules under Section 307 of the Sarbanes-Oxley Act. $^{39}$ That statute required that the SEC establish rules governing professional conduct of lawyers practicing before the Commission, including a rule that would require a lawyer to report evidence of wrongdoing "up the corporate ladder."

When the SEC issued its draft rules in November of $2002,{ }^{35}$ there was some alarm among practitioners that the draft rules were too expansive and went beyond the mandate of the Act. Among other concerns was the SEC's proposal to require a lawyer possessing evidence of uncorrected wrongdoing to make a "noisy withdrawal," flagging for the Commission and the world to see the lawyer's public disavowal of certain documents or conduct.

The final rules are more limited and have deferred action on the "noisy withdrawal" requirement and other, more expansive, measures in the proposed rules. The final rules do retain some measures that may theoretically conflict with some state ethics rules. But the

${ }^{32} I d$. at 1005 .

${ }^{33}$ Standards of Professional Conduct for Attorneys Appearing and Practicing Before the Commission in the Representation of an Issuer, 17 C.F.R. 205 (2003).

${ }^{94}$ Sarbanes-Oxley Act, $\$ 307,15$ U.S.C.A. $\$ 7245$ (West Supp. 2003).

${ }^{85}$ Implementation of Standards of Professional Conduct for Attorneys, 67 Fed. Reg. 71670 (proposed Nov. 21, 2002) (codified at 17 C.F.R. 205 (2003)). 
question is whether we are in danger of a potential federalism Armageddon. I think not.

The Judiciary tends to assert its authority in two discrete areas that are relevant here. The first is separation of powers. Intrusion of executive or legislative branches into judicial processes is viewed skeptically to put it mildly. The second area involves principles of federalism. Here the state judiciaries may be in common league with federal courts as well as state executive and legislative branches in resisting federal intrusion into matters traditionally vested in the states. Governance of the internal affairs of corporations is one of those matters. Another involves lawyer ethics. The Sarbanes-Oxley Act is involved in some of each. It remains to be seen whether this legislation and the rulemaking thereunder will be the high water mark of federalization in these areas, at least for a time.

The Conference of Chief Justices recognizes the authority of Congress expressly to enact the "up-the-ladder" mandate of Section 307 of the Sarbanes-Oxley Act. The scope of the draft rules released in November, however, raised for the Conference interesting questions of the sweep and breadth of federal intervention in state governance of lawyer conduct. But now, as a result of the action of the Commission limiting in the final rules the scope of the earlier draft rules and deferring some proposals, I am less concerned about a wide-ranging ethics regime being undertaken by the Commission.

The ethics argument that seemingly implicates concerns about federalism might be viewed now in a different light than many of us saw it previously. Section 307 and the SEC rulemaking it mandates may not really be ethics rules in the traditional sense. On the one hand, ethics rules are promulgated and enforced by state supreme courts over a broad range of professional conduct. On the other hand, Section 307 of the Sarbanes-Oxley statute and the SEC rules it mandates, though they appear on the surface to be ethics rules, may more clearly be seen as organic law, external to ethics rules. These SEC rules constitute the applicable law regulating lawyers' conduct in a limited area of practice regulation before a federal agency, much like the practice rules of the Internal Revenue Service or the Patent and Trademark Office. Enforcement of the federal securities laws, as distinct from ethics rules, properly belongs to the SEC.

Collision with state supreme court authority over lawyer ethics, therefore, may have been largely obviated, in my personal opinion, as a result of the final rules. When the rules finally promulgated under Section 307 are considered as an external, regulatory, organic law 
limited to the discrete area of securities law, the federalism concerns may be seen in a different light. The Sarbanes-Oxley "up-the-ladder" rule, while it resembles a mandatory form of Model Rule 1.13 applicable to reporting companies, ${ }^{36}$ is, in reality, a regulatory rule much like other commands in the securities area-e.g., disclosure, certification, and the like. Model Rule 1.13 is a broad rule governing the ethics of lawyers for large and small organizations of an infinite variety of shapes and sizes in a vast range of circumstances.

The Model Rules often refer to, or defer to, organic law. So, here, the question is probably not whether the SEC is usurping (in a broad federalization sense) the ethics rules of state supreme courts. The SEC is not rewriting Model Rule 1.13 or 1.6 over a broad range of conduct. Perhaps we need not worry-at least up to this point-that we are in a federalism crisis, insofar as state ethics rulemaking and enforcement are concerned.

\section{CONCLUSION}

The state-based common law of fiduciary duties implicating the internal affairs of corporations will continue to be adjudicated, to a major extent, by the Delaware courts on a case-by-case basis. The coherence of this case law will continue to be debated by scholars on both sides of the property/entity dichotomy.

The federal overlay of Sarbanes-Oxley and the implication of the proposed SRO listing requirements will be interesting and somewhat intrusive in the corporate governance area. But in my view they will not trump most of the state-based statutory or decisional law.

As for lawyers' responsibilities, the stakes are higher in the securities area. But the state-based ethics regime-while it may be influenced as a matter of scrutiny or moral tone in a subtle way by the Sarbanes-Oxley SEC rules-is intact and will continue to function. In my view, there will, however, be a movement toward more cooperation among the SEC and state lawyer disciplinary authorities.

Finally, let me say that I agree with Vice Chancellor Strine's observation about the value of the involvement of Delaware judges in these kinds of academic discussions. It is very helpful for us to hear your views and for our views to be tested by vigorous academic discussion. We are constrained in what we can say, of course, but we need to be exposed to the real world-whether it is academic critique or the

\footnotetext{
${ }^{36}$ Model Rules of Prof'l Conduct R.1.13 (1983).
} 
views of practitioners-and those views will differ, of course. Whether we take these views with a grain of salt or we take them to heart, symposia like this are healthy. 
